\title{
Electroless Nickel Coating Kinetics on TMT Rebar Surface and Coating Characterisation
}

\author{
Manindra MANNA and Nikhilesh BANDYOPADHYAY \\ Research \& Development Department, Tata Steel, Jamshedpur 831001 India. \\ E-mail: manindra.manna@tatasteel.com; nb@tatasteel.com
}

(Received on August 11, 2009; accepted on February 1, 2010)

\begin{abstract}
The corrosion resistance Ni-P-Fe alloy coating was obtained on rebar surface by an electroless process using glycolic acid as a complexing agent. During dipping of the iron scale free rebar in electroless solution, Fe first dissolves and the surface is activated. Subsequently, Ni, P and Fe are co-deposited by an autocatalytic process. The coating was characterised using SEM, EDS and XRD techniques. The weight percentage of $\mathrm{Ni}, \mathrm{P}$ and $\mathrm{Fe}$ in the coating showed a relationship with the coating time. The Tafel and salt spray tests were conducted to find out corrosion resistance performance of coated samples. Electrochemical behavior of the coated rebar in simulated concrete environment is influenced by the $\mathrm{pH}$ of the concrete pore solution and the $\mathrm{P}$ content in the coating. Corrosion potential and the corrosion rate of the coatings increased with the increase in $\mathrm{P}$ content in the coating and $\mathrm{pH}$ of the pore solution whereas the resistance against chloride attack increased with increase in $\mathrm{P}$ content in the coating. Coated rebars showed reduction in bond strength in the range of 8 to $14 \%$ compared to the bare rebars. The maximum ( 14\%) drop in bond strength was observed for longer coating time. This can be attributed to the smoother coating surface. The coating obtained under longer coating time showed higher amount of $P$ which contributed to maximum surface smoothness. However, this bond strength was much above the necessary strength requirement according to Indian standard specification.
\end{abstract}

KEY WORDS: steel reinforced concrete; alkaline corrosion.

\section{Introduction}

Reinforcing bars are widely used in concrete structures such as bridges, dams, flyovers, parking garages, building structures and for general-purpose reinforced concrete. The corrosion of Reinforced Concrete (RC) structures demonstrates very complicated forms of deterioration ${ }^{1-8)}$ but the main reason for the decrease in the durability of RC structures is due to the corrosion of the reinforcing bar. In concrete, the alkaline pore solution passivates the metal surface so that it does not rust/corrode. ${ }^{8)}$ Due to the carbonation reaction, the $\mathrm{pH}$ of the concrete environment decreases with time $^{9)}$ and the steel converts from the passive to the active state. Coastline structures are deteriorated drastically due to the corrosion of the embedded steel, in spite of the alkaline nature of the concrete environment. The influence of the chloride ions in depassivating the steel surface even at high $\mathrm{pH}$ levels can be seen as a function of the net balance between two competing processes, stabilization (and repair) of the film by hydroxyl ions and disruption of the film by chloride ions. ${ }^{8)}$ For this reason, many studies have been carried out to find out the best method of preventing the corrosion in reinforcing bar. ${ }^{10-22)}$

$\mathrm{Ni}$ has an excellent corrosion resistance property against chloride and hence, is one of the ideal metals for coating on rebar surface. Ni coating on rebar surface by electro-deposition technique is unsuitable due to non-uniform surface geometry. On the rebar surface ribs are exist at regular interval. Hence, Ni coating by electroless process will be one of the viable processes. Electroless nickel (EN) coating has been found to be suitable for variety of applications including the chemical, food, and automotive industries. ${ }^{23)}$ This process gives uniform coating with excellent chemical, mechanical and wears resistance properties. ${ }^{24-27)}$ EN coating can be applied on different substrates (conductive and nonconductive) and is deposited homogeneously regardless of the substrate geometry. ${ }^{28)}$ Once the first layer of nickel is deposited, it acts as a catalytic agent for the plating process. As a result, a linear relationship between the coating and deposition time has been observed. ${ }^{29)}$ EN coating is produced by the autocatalytic reduction of nickel in the presence of sodium hypophosphite $\left(\mathrm{NaH}_{2} \mathrm{PO}_{2}\right)$, producing an alloy of nickel and phosphorus. ${ }^{30)}$ The $\mathrm{Ni}$ and $\mathrm{P}$ contents in the alloy coating are governed by the composition, temperature and the $\mathrm{pH}$ of the plating solution. ${ }^{31)}$ Flis and Duquette $^{32)}$ evaluated Ni-P alloys in near neutral and alkaline solutions and found both beneficial and detrimental effects depending upon the amount of $\mathrm{P}$ in the coating. It is generally accepted that a microcrystalline and amorphous or a co-existence of these two phases can be obtained depending on the P content. ${ }^{30,33-36)}$ Also it has been claimed that the coating is totally amorphous in nature. ${ }^{25,37)}$ Amorphous film has greater corrosion resistance than crystalline film. ${ }^{38)}$ Limited research work has been done to find out the feasi- 
bility of EN coating on rebar surface for application in concrete structure. ${ }^{39,40)}$ Main drawback associated with this process is that coating kinetics is very slow and hence, longer coating time is needed to achieve the desired coating thickness. ${ }^{39)}$

The objective of the present work is to achieve the desired coating using a glycolic acid bath under shorter than earlier coating time. ${ }^{39)}$ Also, coating characterisation for application in concrete structure.

\section{Experimental Procedure}

The TMT (thermo mechanical treatment) rebar used for the experimental study was $10 \mathrm{~mm}$ in diameter. The basic composition of TMT material in weight percent is given in Table 1.

The composition of the steel was analysed using optical emission spectrometer according to ASTM E 415-99a standard. ${ }^{41)}$ The rebar was first subjected to acid pickling to remove iron scale. The scale free rebar was then coated in EN coating solution for different time. The process condition for EN coating is given in Table 2.

The microstructure of the EN coated layer was characterised by scanning electron microscopy (SEM. JEOL JXA 6400). An Energy Dispersive Spectroscopy (KEVEX Super dry detector) was used to determine the elemental distribution through the depth of the coated layer. The structure of the coating was determined using X-ray diffraction (XRD, Philips Analytical X-ray B. V. Machine). Tafel test was conducted for coated and un-coated rebars in simulated concrete pore solutions contaminated with $3.5 \%$ chloride under various $\mathrm{pH}(7,11$ and 13.6) conditions to find out corrosion rate and Ecorr using the Gamry DC105 system. The composition of the concrete pore solution was formulated according to the composition described by Christensen et $a l^{42)}$ consisted of $0.32 \mathrm{~mol} / \mathrm{L} \mathrm{KOH}, 0.17 \mathrm{~mol} / \mathrm{L} \mathrm{NaOH}$ and $0.07 \mathrm{~mol} / \mathrm{L} \mathrm{Ca}(\mathrm{OH})_{2}$ in distilled water and initial $\mathrm{pH}$ was 13.6. The $\mathrm{pH}$ of simulated concrete pore solution dropped

Table 1. Basic composition of TMT material in $w t \%$.

\begin{tabular}{ccccccc}
\hline $\mathrm{C}$ & $\mathrm{Si}$ & $\mathrm{Mn}$ & $\mathrm{P}$ & $\mathrm{Cu}$ & $\mathrm{Al}$ & $\mathrm{Fe}$ \\
\hline 0.12 & 0.35 & 0.64 & 0.03 & 0.035 & 0.042 & $\sim 98.79$ \\
\hline
\end{tabular}

Table 2. Process conditions for electroless nickel coating.

\begin{tabular}{cccccc}
\hline $\begin{array}{c}\mathrm{NiSO}_{4} 6 \mathrm{H}_{2} \mathrm{O} \\
\mathrm{g} / \mathrm{L}\end{array}$ & $\begin{array}{c}\mathrm{NaH}_{2} \mathrm{PO}_{2} \\
\mathrm{~g} / \mathrm{L}\end{array}$ & $\begin{array}{c}\text { Glycolic acid } \\
\mathrm{ml} / \mathrm{L}\end{array}$ & $\mathrm{pH}$ & $\begin{array}{c}\text { Temperature } \\
{ }^{6} \mathrm{C}\end{array}$ & $\begin{array}{c}\text { Treatment time } \\
\text { (minutes) }\end{array}$ \\
\hline 50 & 25 & 30 & 6.85 & $85-90$ & $10-30$ \\
\hline
\end{tabular}

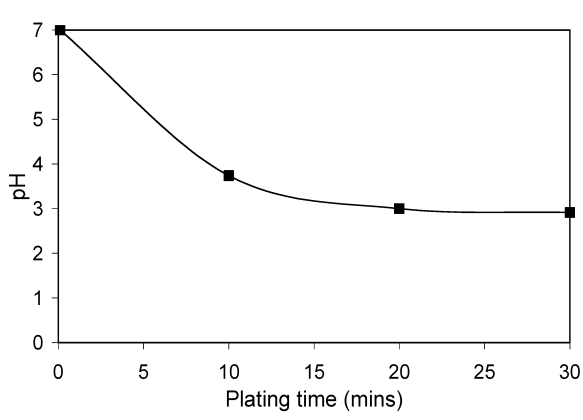

(a) down with time due to carbonation reaction. The scan rate and immersion time for Tafel test were $1 \mathrm{mV} / \mathrm{s}$ and $600 \mathrm{~s}$ respectively. To evaluate the resistance of the coatings against chloride attack, salt spray test was conducted in accordance with ASTM B117 standard. ${ }^{43)}$ The bond strength of the rebar surface with concrete structure was evaluated as par Indian standards (IS) $1786(1985) .{ }^{44)}$ All the coated and uncoated rebars were cast in square concrete blocks. Quick setting cement (Convextra GP2) was used for casting and the curing time was varied from 48 to $60 \mathrm{~h}$ to achieve crushing strength in the range of $200-300 \mathrm{~kg} / \mathrm{cm}^{2}$ of the concrete structure according to the IS. After curing of all blocks, relationship between load versus slip was measured using a tensile testing machine (100 KN FUT make tensile testing machine) fitted with an appropriate precision slip measuring device as par IS: 1786 (1985).

\section{Results and Discussion}

\subsection{Kinetics of Electroless Nickel Coating Process}

During dipping of the scale free rebar in EN solution, $\mathrm{Fe}$ first dissolves and the surface is activated. Subsequently, $\mathrm{Ni}, \mathrm{P}$ and Fe are co-deposited on the activated rebar surface. This first deposit acts as a catalytic agent for subsequent deposition of metal and non-metal. The EN process proceeds by a single anodic and four cathodic reactions. ${ }^{38)}$

Anodic reaction:

(i) $\mathrm{H}_{2} \mathrm{PO}_{2}^{-}+\mathrm{H}_{2} \mathrm{O} \rightarrow \mathrm{H}_{2} \mathrm{PO}_{3}^{-}+2 \mathrm{H}^{+}+2 \mathrm{e}^{-}$

Cathodic reactions:

(i) $\mathrm{Ni}^{2+}+2 \mathrm{e}^{-} \rightarrow \mathrm{Ni}^{0}$

(ii) $\mathrm{H}_{2} \mathrm{PO}_{2}^{-}+2 \mathrm{H}^{+}+\mathrm{e}^{-} \rightarrow \mathrm{P}+2 \mathrm{H}_{2} \mathrm{O}$

(iii) $\mathrm{Fe}^{2+}+2 \mathrm{e}^{-} \rightarrow \mathrm{Fe}^{0}$

(iv) $2 \mathrm{H}^{+}+2 \mathrm{e}^{-} \rightarrow \mathrm{H}_{2}$

The $\mathrm{H}^{+}$ions are being generated and consumed by an anodic and two possible cathodic reactions (ii and iv) respectively. Elemental Ni, P and Fe are deposited on the rebar surfaces by cathodic reactions $\mathrm{i}$, ii and iii. The predominant cathodic reactions are $\mathrm{Ni}^{2+}$ and $\mathrm{H}^{+}$ions reduction. It is evident from all anodic and cathodic reactions that electroless deposition process is advanced by a cumulative generation of $\mathrm{H}^{+}$ions, resulting in drop of $\mathrm{pH}$ in the coating solution as shown in Fig. 1(a).

The EN deposition kinetics is controlled by the concentration of hydrogen ions in the coating solution. The anodic reaction rate is decreased with coating time. As a result, the cathodic reaction rate is also decreased. However, the hydrogen evolution rate is still in the higher range due to

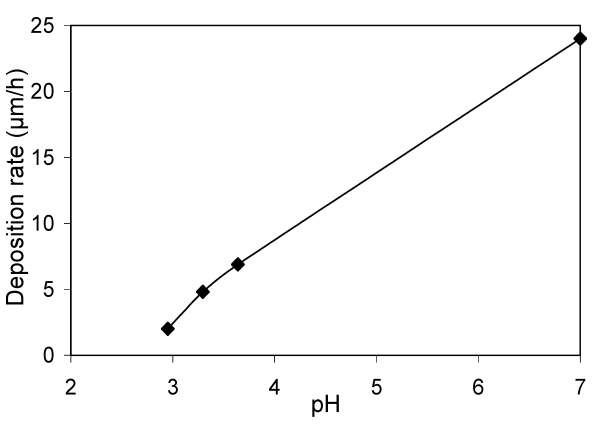

(b)

Fig. 1. Effect of plating time on (a) bath $\mathrm{pH}$ and (b) metal deposition rate. 
higher concentration of $\mathrm{H}^{+}$ions, as a consequent deposition rate of metal and non-metal is decreased drastically with elapse of coating time as shown in Fig. 1(b).

\subsection{Characterisation of EN Coated Layer}

Figures 2 and $\mathbf{3}$ show the cross sectional SEM micrographs of the coated layer and elemental depth profiles of $\mathrm{Ni}, \mathrm{P}$ and $\mathrm{Fe}$ of these coated layers for different coating time of 10, 20 and 30 min respectively. Increased in coating thickness is found to be marginal with increase in plating time as evident from SEM micrograph in Fig. 2. Approximate coating thickness after different treatment time is given in Table 3. The point P8 in Fig. 2 indicates the steel substrate.

The quantitative elemental depth profile by EDS indicates $\mathrm{Ni}, \mathrm{P}$ and $\mathrm{Fe}$ content is changed through the coating thickness as shown in Fig. 3. The points P1 and P7, shown in Fig. 3 represent the outer coating layer and substratecoating interface respectively of all the coatings.

The $P$ percentage increased from substrate-coating interface to the outer coating layer, whereas Fe percentage decreased from substrate-coating interface to the outer coating layer. On the other hand, Ni content increased from outer surface to a certain depth in the coating and further decreased towards substrate coating interface. The comparative concentration of $\mathrm{Ni}^{2+}, \mathrm{Fe}^{2+}$ and $\mathrm{H}^{+}$ions with coating time in the solution plays an important role (on coating composition and kinetics) for such elemental depth profile of all the coatings. It is also evident from elemental depth profile that the $\mathrm{P}$ content at the outer layer of the coating increased with coating time whereas $\mathrm{Fe}$ and $\mathrm{Ni}$ content at the outer layer decreased with coating time. The $\mathrm{P}$ deposition rate increased with drop of $\mathrm{pH}$ in the solution. The $\mathrm{X}$-ray diffraction (XRD) result confirms that the structure of the coating is amorphous (as shown in Fig. 4) in nature irrespective of coating time or $\mathrm{P}$ content in the coating.

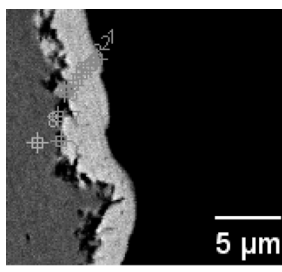

(a)

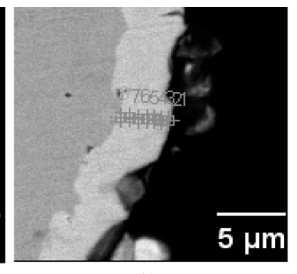

(b)

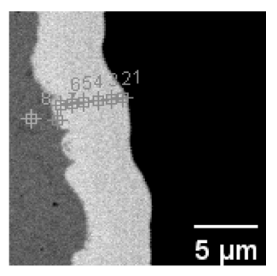

(c)
Fig. 2. SEM micrograph of coated layer for different coating time of (a) 10, (b) 20 and (c) $30 \mathrm{~min}$.

\subsection{Electrochemical Behaviour of the Coating in Sim- ulated Concrete Pore Solution}

The electrochemical behaviour of all the coated and uncoated rebars in simulated concrete pore solution under various $\mathrm{pH}$ conditions is shown in Fig. 5.

The free corrosion potentials of all three coated and uncoated rebars depend on the $\mathrm{pH}$ of the pore solution. The free corrosion potential of all three coated rebars is more noble to that of the un-coated rebar in neutral $(\mathrm{pH}=7)$ or mildly $(\mathrm{pH}=11)$ alkaline pore solution containing $3.5 \%$ chloride whereas the free corrosion potential of the coated rebar for the coating obtained under coating time of 20 and $30 \mathrm{~min}$ are less active to that of un-coated rebar in highly alkaline $(\mathrm{pH}=13.6)$ pore solution containing $3.5 \%$ chloride. It is evident that the free corrosion potential of the coating shifted towards more active direction with increase in $\mathrm{P}$ content in the coating, irrespective of $\mathrm{pH}$ in the pore solution. The corrosion rate or more precisely the dissolution rate of all the coated rebars depends strongly on $\mathrm{pH}$ of the pore solution and the $\mathrm{P}$ content. The dissolution rate of all three coated rebars is slower than the un-coated rebar in neutral $(\mathrm{pH}=7)$ or mildly alkaline $(\mathrm{pH}=11)$ pore solution. The coating which was obtained under longer coating time shows slowest dissolution rate. On the other hand, the coating obtained under longer coating time dissolves faster in highly alkaline $(\mathrm{pH}=13.6)$ pore solution. The dissolution

Table 3. Approximate coating thickness after different treatment time.

\begin{tabular}{cc}
\hline Treatment time (minutes) & Thickness of the coating $(\mu \mathrm{m})$ \\
\hline 10 & 3 \\
20 & 4.5 \\
30 & 5.5 \\
\hline
\end{tabular}

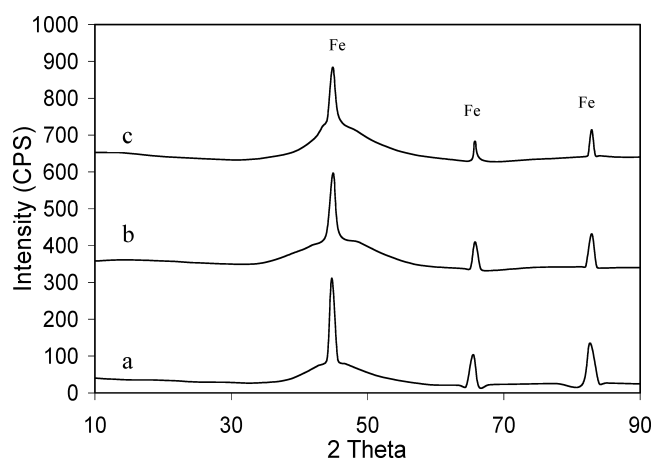

Fig. 4. X-ray diffraction peaks of coated rebar surfaces for different plating times of (a) 10, (b) 20 and (c) $30 \mathrm{~min}$.

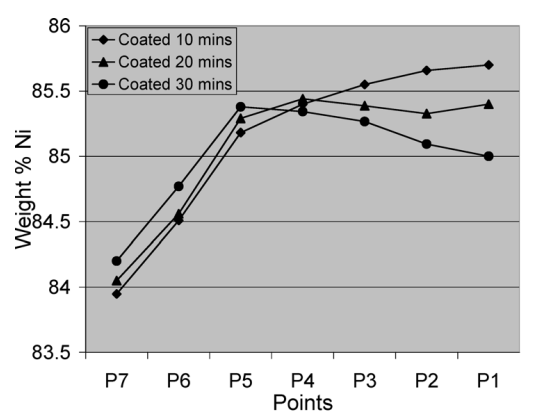

(a)

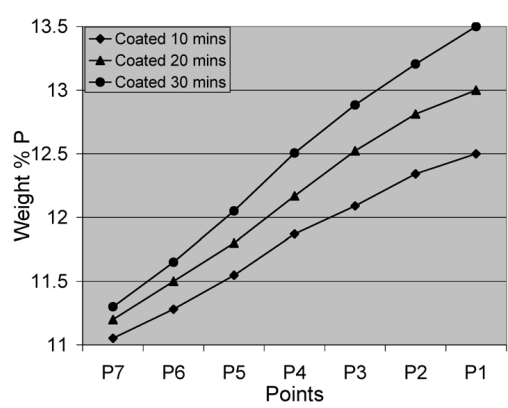

(b)

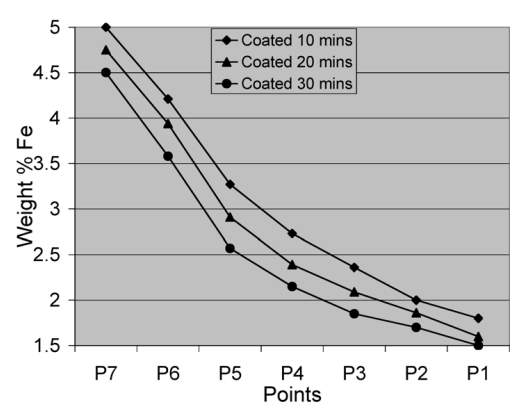

(c)

Fig. 3. Elemental depth profile by EDS of (a) Ni, (b) P and (c) Fe of different coated layers. 


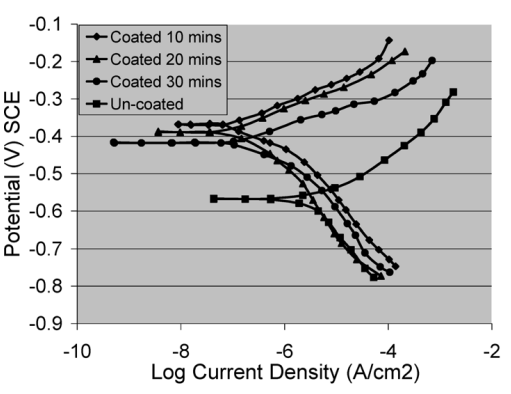

(a)

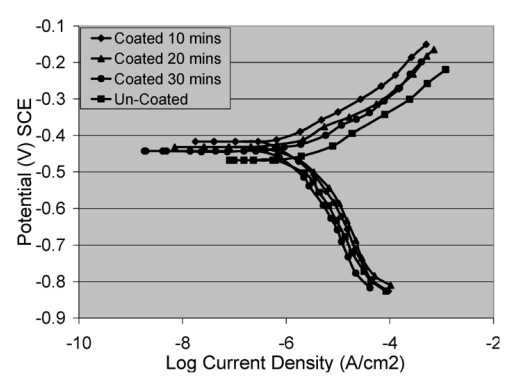

(b)

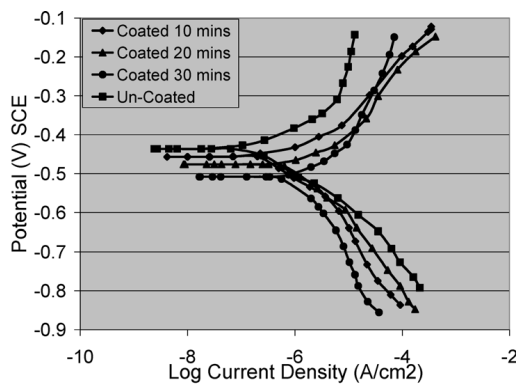

(c)

Fig. 5. Polarization curves of un-coated and different coated rebars in simulated pore solution contaminated with $3.5 \%$ chloride with pH (a) 7, (b) 11 and (c) 13.6.

Table 4. $E_{\text {corr }}$ and corrosion rate of un-coated and different coated rebars (coating time: 10, 20 and $30 \mathrm{~min}$ ) in concrete pore solution contaminated with $3.5 \%$ chloride under varying $\mathrm{pH}$ conditions.

\begin{tabular}{lccc}
\hline Material history & Environment & Ecorr $(\mathrm{V})$ & Corrosion rate $(\mathrm{mm} / \mathrm{y})$ \\
\hline Coated $10 \mathrm{mins}$ & $3.5 \% \mathrm{Cl}$ and $\mathrm{pH}=7$ & -0.361 & 0.00538 \\
Coated $20 \mathrm{mins}$ & same & -0.388 & 0.00226 \\
Coated $30 \mathrm{mins}$ & same & -0.417 & 0.00109 \\
Un-coated & same & -0.568 & 0.03439 \\
Coated $10 \mathrm{mins}$ & $3.5 \% \mathrm{Cl}$ and $\mathrm{pH}=11$ & -0.415 & 0.00625 \\
Coated $20 \mathrm{mins}$ & same & -0.432 & 0.00284 \\
Coated $30 \mathrm{mins}$ & same & -0.441 & 0.00160 \\
Un-coated & same & -0.468 & 0.00716 \\
Coated $10 \mathrm{mins}$ & $3.5 \% \mathrm{Cl}$ and $\mathrm{pH}=13.6$ & -0.459 & 0.00874 \\
Coated $20 \mathrm{mins}$ & same & -0.486 & 0.01158 \\
Coated 30 mins & same & -0.506 & 0.01935 \\
Un-coated & same & -0.435 & 0.00208 \\
\hline
\end{tabular}

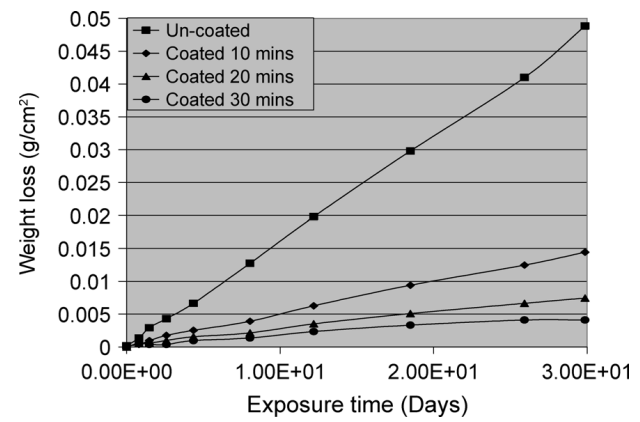

Fig. 6. Weight loss of different coated and un-coated rebars in aggressive chloride environment.

rate of the coating obtained under $30 \mathrm{~min}$ of coating time is even faster than un-coated rebar in highly alkaline $(\mathrm{pH}=13.6)$ pore solution. The free corrosion potential and the corrosion rate of all three coated and un-coated rebars in simulated concrete pore solution under varied $\mathrm{pH}$ condition is shown in Table 4.

\subsection{Accelerated Corrosion Test in Aggressive Chloride Environment}

Figure 6 shows the dissolution rate of un-coated and three coated (coating time: 10, 20 and $30 \mathrm{~min}$ ) rebars in aggressive chloride environment. It is evident that all the coatings have much more resistance $(\Omega)$ power against chloride attack than un-coated rebar. It is also evident that the coating obtained under longer plating time showed maximum resistance against chloride attack.

\subsection{Pull-out Test Results}

The comparative bond strength of all three coated as well

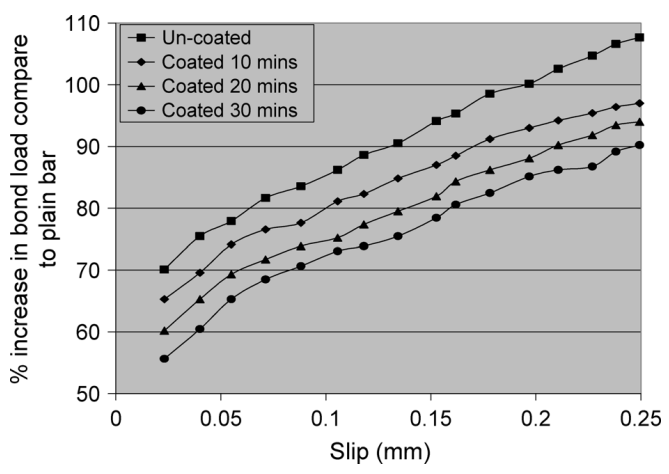

Fig. 7. Comparative bond strength of un-coated and different coated rebars with concrete structure.

Table 5. Roughness of the uncoated and different EN coated rebar surfaces.

\begin{tabular}{lcccc}
\hline $\begin{array}{c}\text { Surface } \\
\text { Condition }\end{array}$ & Uncoated & $\begin{array}{c}10 \text { minutes } \\
\text { EN coated }\end{array}$ & $\begin{array}{c}20 \text { minutes } \\
\text { EN coated }\end{array}$ & $\begin{array}{c}30 \text { minutes } \\
\text { EN coated }\end{array}$ \\
\hline $\begin{array}{c}\text { Roughness } \\
(\mu \mathrm{m})\end{array}$ & 1.95 & 1.214 & 0.873 & 0.578 \\
\hline
\end{tabular}

as un-coated rebars surface with concrete structure is shown in Fig. 7.

The vertical label in Fig. 3 shows the percentile increment in bond strength with ribbed bar in concrete structure compared to the bar without any rib of same diameter in same structure.

All the coated rebars showed drop in bond strength in the range of 8 to $14 \%$. The maximum $(\sim 14 \%)$ drop in bond strength was observed for longer coating time. This can be attributed to the smoother coating surface. The coating obtained under longer coating time showed higher amount of $P$ which contributed to maximum surface smoothness (see Table 5). The EN coating with higher amount of $P$ is expected to be providing better amorphous structure compared to the coating with lower amount of $\mathrm{P}$.

However, this bond strength was much above the necessary strength requirement as par Indian standard specification.

\section{Conclusions}

(1) The corrosion resistant of Ni-P-Fe amorphous alloy coating was obtained on rebar surface using glycolic acid as a complexing agent. The solution $\mathrm{pH}$ was found to play a strong role on process kinetics and composition but not on the coating structure. Desired coating under shorter 
coating time is possible under $\mathrm{pH} \sim 7$ of the plating solution.

(2) The electrochemical behaviour of all the coated rebars in simulated concrete environment was found to dependent on $\mathrm{pH}$ of the concrete pore solution and the $\mathrm{P}$ content in all the coatings. The corrosion potential as well as corrosion rate of the coated rebar increased with increase in $\mathrm{P}$ content in the coating and $\mathrm{pH}$ of the pore solution.

(3) The resistance to chloride attack of the coated rebar increased with increase in $\mathrm{P}$ content in the coating, as observed in salt spray tests.

(4) All the coated rebars showed reduction in bond strength in the range of 8 to $14 \%$ compared to the bare rebars. The maximum $(\sim 14 \%)$ drop in bond strength was observed for longer coating time. This can be attributed to the smoother coating surface. The coating obtained under longer coating time showed higher amount of P which contributed to maximum surface smoothness. The EN coating with higher amount of $\mathrm{P}$ is expected to be providing better amorphous structure compared to the coating with lower amount of P. However, this bond strength was much above the necessary strength requirement as par Indian standard specification.

\section{Acknowledgements}

The author is grateful to Tata Steel for allowing the research work in technical journal and also grateful to Prof. R. C. Behera of NIT Rourkela, for conducting XRD analysis of EN coated rebar surface. The assistance of Ms. Nitu Rani and Mr. V. Sharma in conducting experiments and characterisation studies is also gratefully acknowledged.

\section{REFERENCES}

1) G. S. Duffo, W. Morris, I. Raspini and C. Saragovi: Corros. Sci., 46 (2004), 2143.

2) M. Moreno, W. Morris, M. G. Alvarez and G. S. Duffo: Corros. Sci., 46 (2004), 2681.

3) P. Garcés, M. C. Andrade, A. Saez and M. C. Alonso: Corros. Sci., 47 (2005) 289.

4) S.-H. Tae, J. W. Kyung and T. Ujiro: ISIJ Int., 47 (2007), No. 6, 875

5) R. Lyons, M. Ing and S. Austin: Corros. Sci., 47 (2005), 413.

6) J. A. Gonzalez, J. M. Miranda and S. Feliu: Corros. Sci., 46 (2004), 2467.

7) M. Castellote, C. Andrade and C. Alonso: Corros. Sci., 44 (2002), 2409.

8) D. D. N. Singh, R. Ghosh and B. K. Singh: Corros. Sci., 44 (2002), 1713.

9) S.-H. Tae, H.-S. Lee, T. Noguchi, T. Ujiro and S. W. Shin: ISIJ Int., 46 (2006), No. 7, 1075.
10) S.-H. Tae, T. Noguchi and T. Ujiro: ISIJ Int., 46 (2006), No. 10, 1467.

11) S.-H. Tae and T. Ujiro: ISIJ Int., 47 (2007), No. 9, 1324

12) S.-H. Tae, H.-S. Lee, T. Noguchi, T. Ujiro and S. W. Shin: ISIJ Int., 46 (2006), No. 7, 1086

13) A. Bentur, S. Diamond and N. S. Berke: Steel Corrosion in Concrete, Chapman \& Hall, London, (1997), 27.

14) P. Garcés, M. C. Andrade, A. Saez and M. C. Alonso: Corros. Sci., 47 (2005), 289.

15) S.-H. Tae and T. Ujiro: ISIJ Int., 47 (2007), No. 5, 715.

16) A. Sanjurjo, S. Hettiarachchi, K. H. Lau, P. Cox and B. Wood: Surf. Coat. Technol., 54/55 (1992), 224.

17) M. Manna, I. Chakrabarti and N. Bandyopadhyay: Surf. Coat. Technol., 201 (2006), 1583.

18) S.-H. Tae, T. Noguchi and T. Ujiro: ISIJ Int., 47 (2007), No. 1, 146.

19) M. Manna: Surf. Coat. Technol., 203 (2009), 1993.

20) M. Manna: Corros. Sci., 51 (2009), 451.

21) M. A. Sanchez: Corros. Rev., 19 (2001) 105.

22) M. Manna, G. Naidu, N. Rani and N. Bandyopadhyay: Surf. Coat. Technol., 202 (2008), 1515.

23) F. Simescu and H. Idrissi: Corros. Sci., 51 (2009), 833.

24) J. Colaruotolo and D. Tramontana: Electroless Plating, ed. by G. O. Mallory and J. B. Hajdu, American Electroplaters' and Surface Finishers Society, Orlando, FL, (1990), 207.

25) M. Manna: Surf. Coat. Technol., 204 (2010), 1842.

26) R. N. Duncan: Met. Prog., 127/7 (1985), 31

27) K. S. Rajam, I. Rajagopal and S. R. Rajagopalan: Met. Finish., 88 (1990), 77.

28) Y. Okinaka and T. Osaka: Advances in Electrochemical Science and Engineering, Vol. 3, ed. by H. Gerischer and C. W. Tobias, $\mathrm{VCH}$, Weinheim, Germany, (1994), 55.

29) D. Barker: Trans. Inst. Met. Finish., 71 (1993), 121

30) R. N. Duncan: Plat. Surf. Finish., 83 (1996), 65.

31) G. G. Gavrilov: Chemical (Electroless) Nickel Plating, Redhill, Portcullis Press, UK, (1979), 189.

32) J. Flis and D. J. Duquette: Corrosion, 41 (1985), 700.

33) E. Vafaei-Makhsoos, E. L. Thomas and L. E. Toth: Metall. Trans. A, 9A (1978), 1449

34) R. M. Allen and J. B. Van der Sande: Scr. Metall., 16 (1982), 1161.

35) S. V. S. Tyagi, V. K. Tandon, and S. Ray: Z. Metallkd., 76 (1985), 492.

36) K. H. Hur, J. H. Jeong and D. N. Lee: J. Mater. Sci., 25 (1990), 2573.

37) J. N. Balaraju and S. K. Seshadri: Met. Finish., 97 (1999), 8.

38) A. G. Revesz and J. Kruger: Passivity of Metals, ed. by R. P. Krankenthal, Electrochemical Society, Princeton, NJ, (1978), 137.

39) M. Manna, N. Bandyopadhyay and D. Bhattacherjee: Surf. Coat. Technol., 202 (2008), 3228.

40) D. D. N. Singh and R. Ghosh: Surf. Coat. Technol., 201 (2006), 90.

41) ASTM E 415-99a, ASTM International, 100 Barr Harbar drive, PO Box C700, West Conshohocken, PA 19428-2959, US, (2005).

42) B. J. Christensen, T. O. Mason and H. M. Jennings: J. Am. Ceram. Soc., 75 (1992), 939.

43) ASTM B117-03, ASTM International, 100 Barr Harbar drive, PO Box C700, West Conshohocken, PA 19428-2959, US, (2009).

44) IS-1786 (1985), Indian Standards Specification, New Delhi, India, (1992). 